\title{
JEWISH PILGRIM FESTIVALS AND CALENDAR IN PAUL’S MINISTRY WITH THE GENTILE CHURCHES
}

\author{
Jin K. Hwang
}

\section{Summary}

It is quite remarkable that Paul explicitly mentions two of the Jewish pilgrim festivals, namely, the Passover and Pentecost in 1 Corinthians (5:7-8; 16:8). This study argues that such festivals played a key role not only in providing Paul with the biblical foundations for his exhortations in 1 Corinthians (as indicated in ch. 5) but also in shaping his ministry with the Gentile churches at Corinth, Ephesus, Galatia, and Macedonia, and his collection project in particular, which entails the pilgrimage to Jerusalem by representatives from his Gentile churches, most likely during a Jewish festival (as indicated in ch. 16).

\section{Introduction}

In 1 Corinthians, Paul mentions two of the Jewish pilgrim festivals, ${ }^{1}$ namely, the Passover and Pentecost. In chapter 5 he identifies Christ with the paschal lamb and asks the Corinthian believers to celebrate the festival with unleavened bread. In chapter 16 he makes it clear that he will have to stay at Ephesus until Pentecost. These references are quite remarkable as he mentions no such Jewish festivals by name elsewhere in his letters (cf. Rom. 14:5; Gal. 4:10; Col. 2:16; Acts 20:6). Why then did Paul specifically mention the Passover and Pentecost in 1 Corinthians? How did such Jewish festivals shape his ministry for the Gentile churches at Corinth and Ephesus and his argumentation in

1 A revision of the paper presented at the Society of Biblical Literature annual meeting, on 21 November 2009, in New Orleans, Louisiana. 
1 Corinthians? The present paper will attempt to answer these questions and consider the implications for the study of early JewishChristian relations.

\section{Calendars, Festivals, and Jewish Identity in the First- Century Hellenistic World}

As Sacha Stern suggests, ${ }^{2}$ calendar reckoning can be one of the important indicators of the self-identity of a religious group. Hence, it is important to consider the distinctiveness of the Jewish calendar reckoning in the first-century Graeco-Roman world, which also appears to have had a profound influence on the early Christians' beliefs and practices.

The official calendar of the Roman Empire in the First Century was the Julian calendar. This calendar, having twelve months with 365 days in a year and one additional day in every four leap years, was a solar calendar by nature (Dio Cassius, Roman History 43:26:1-3; Pliny, Nat. 18:210-12), whereas the pre-Julian calendar regulated by Romulus and then modified by Numa had been a lunar one (Ovid, Fasti 1:27-28; Livy, Ab Urbe Condita 1:19:6). The Julian calendar had made a few significant permanent changes in the order and names of months: February, which Numa counted as the twelfth month, had become the second month; Quintilis had been renamed Iulius (July); and Sextilis became Augustus (August) (Dio Cassius, Roman History 44:5:2; Macrobius, Saturnalia 1:12:34-35; Suetonius, Augustus 31:2, cf. also Suetonius, Caligula 15:2). Each day in a month-whether in the preJulian or Julian calendar-was designated in terms of its relationship to one of the three fixed days: the Kalends, the Nones, or the Ides. ${ }^{3}$ For example, in Fasti, a poetical treatise on the Roman calendar completed in or around AD 8, Ovid designates each day of a month in the Julian calendar by using one of these terms and explains it from historical,

2 Sacha Stern, 'Jewish Calendar Reckoning in the Graeco-Roman Cities' in Jews in the Hellenistic and Roman Cities, ed. John R. Bartlett (London/New York: Routledge, 2002): 114.

3 Denis Feeney, Caesar's Calendar: Ancient Time and the Beginnings of History (Sather Classical Lectures, 65; Berkeley/Los Angeles/London: University of California Press, 2007): 152-53. The Kalends falls on the first day of the month, while the Nones on the fifth or eighth, and the Ides in the middle. 
religious, and/or astronomical perspectives (cf. also Pliny, Nat. 18:214 and passim).

Civil life in the empire in the First Century was governed by a distinction between public business days (Fasti) and non-business days (Nefasti), which was enacted by Numa (Livy, Ab Urbe Condita 1:19:7; Ovid, Fasti 1:45-52), and by an eight-day week cycle (A to H), which revolves around a periodic market day, called nundinae (Ovid, Fasti 1:54; Macrobius, Saturnalia 1:16:34). ${ }^{4}$ The first-century Roman world also knew the astrological seven-day week cycle, as can be illustrated by a first-century Pompeian graffito (CIL IV 8863) that lists the seven days (dies) named after pertinent planets alongside the names of the towns where there would be a market day (nundinae). ${ }^{5}$ We can know from another Pompeian graffito (CIL IV 4182) that at least two of those towns had a different market day during the reign of Nero: the nundinae for Cumae was eight days before the Ides of February, on Sunday (dies Solis), sixteenth day from the first moon; while Pompeii had it three days later, namely, five days before the Ides of February. It seems therefore that the seven-day cycle of the week (and arguably even that of a market day) also existed in the empire in the First Century, while the eight-day week cycle still remained official. ${ }^{6}$ But it

4 The eight-day week cycle can be presented both by a pre-Julian calendar noted above (Fasti Antiates Maiores) and a first-century Julian calendar (Atilius Degrassi, Inscriptiones Italiae, vol. 13, Fasti et Elogia, Fasc. 2, Fasti anni Numani et Iuliani [Rome: Instituto poligrafico dello stato, 1963]: 2; David E. Duncan, Humanity's Epic Struggle to Determine a True and Accurate Year [New York: An Avon Book, 1998]: 36; Feeney, Caesar's Calendar, 183). Eviatar Zerubavel (The Seven Day Circle: The History and Meaning of the Week [New York: The Free Press, 1985]: 46) points out that as the empire expanded, the eight-day week cycle revolving around a periodic market day began to decline significantly. But from the above-mentioned inscription noted by Duncan and Feeney, it can be said that the eight-day week cycle was still governing the civil life of the empire in the First Century.

5 Chris Bennet, 'The Imperial Nundinal Cycle', ZPE 147 (2004): 176, notes that CIL IV 8863 not only provides a hint about a seven-day week cycle but also reveals a way of counting days in a lunar month (with thirty days).

6 In the early Fourth Century AD, Dio Cassius also states: 'The custom, however, of referring the days to the seven stars called planets was instituted by the Egyptians, but is now found among all mankind, though its adoption has been comparatively recent; at any rate the ancient Greeks never understood it, so far as I am aware. But since it is now quite the fashion with mankind generally and even with the Romans themselves' (Roman History 37.18.1-2 [LCL 53]). 
was not until Constantine's edict in AD 321 that the seven-day week cycle was officially adopted into the Roman calendar system. ${ }^{7}$

It is interesting to note that in many Hellenistic cities in the empire, the Macedonian dates were still preferred even after the Julian calendar reform because of the Hellenistic influence. For this reason, the Julian dates were often translated into the Macedonian ones although month names varied from place to place. ${ }^{8}$

With regard to the Diaspora Jews in the Hellenistic cities of the First Century, there is almost no literary or paraliterary evidence that they fully adopted the Roman calendar system. ${ }^{9}$ The Macedonian system seems to have been much more prevalent among the Jews in Syria, both before and after the Julian reform. For example, a third-century $\mathrm{AD}$ grave stone from Palmyra in Syria specifies the date in both

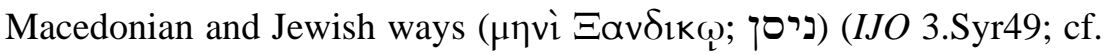
also IJO 3.Syr58; 2 Macc. 11:21, 30, 33, 38). ${ }^{10}$ The situation may not have been much different with the Jews in other Hellenistic cities in the empire. There are some first-century AD Jewish inscriptions from the coastal cities at the Black Sea in which the Macedonian dates appear (IJO 1.BS5; 6; 17; 18; 20; 22). Also, on a gravestone of a Jewish family from Phrygian Hierapolis, the Feast of Unleavened Bread is said

7 Duncan, Humanity's Epic Struggle, 44. But Duncan also mentions that 'Even after Constantine's edict about Sunday, it took another generation or two for the seven-day week to catch on throughout the empire' (47).

8 For example, in Asia Minor a year was considered to have 365 days just as in the Julian calendar, but Augustus's birthday (a.[ante] d.[diem] IX Kal, Oct $=23$ September) had been made the head of the year and named 1 Kaisarios, which is another name for Dios. For various month names in Roman provinces, see further Bradley Hudson McLean, An Introduction to Greek Epigraphy of the Hellenistic and Roman Periods from Alexander the Great Down to the Reign of Constantine (323 BC$A D$ 337) (Ann Arbor: University of Michigan Press, 2002): 170 (Table 14).

9 Josephus mentions the Ides of December (Ant. 14.145) and the Ides of February (Ant. 16.172) when he cites the public letters/decrees of the Roman officials to the Jews. Cf. also CIJ 2.650 (dated AD 383, where a Jewish lunar date is written alongside the Julian); IJO 2.196 (dated later than the Third Century AD, where a reference is made to the Feast of Kalends, the Roman New Year festival); IJO 1.Dal4 (dated 18 August AD 539, where the Roman calendar system is indicated); Mart. Pol. 21:1 (dated the Second Century AD, where the martyrdom of Polycarp, a bishop of Smyrna

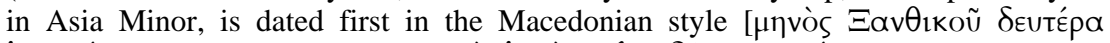

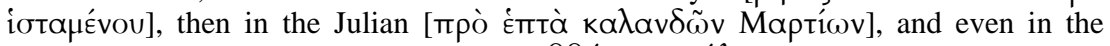

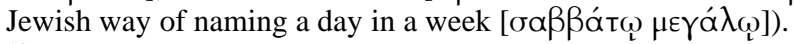

10 The Macedonian dates are also attested in the papyri from Dura-Europos in Syria as late as the Third Century AD along with (P.Dura 29; 30; 32) or without the Roman ones (P.Dura 20; 23; 31; 34; 129). They may not reveal a Jewish practice of calendar reckoning but certainly demonstrate the strong tendency for the Macedonian calendar system in the Hellenistic cities of the First Century. 
to fall on the 'seventh [Macedonian] month' (March/April in the Julian calendar), and the Roman New Year Day on the eighth day of the 'fourth [Macedonian] month' (December/ January) (IJO 2:196, dated later than the Third Century AD). This indicates that a Jew in Asia Minor might still have preferred the Macedonian dates to the Roman (Julian) ones as late as the Third Century AD. ${ }^{11}$

But the Diaspora Jews in the Hellenistic cities also persisted in their own way of calendar reckoning so that they could celebrate their own religious festivals in accordance with their Scriptures and ancestral traditions. They depended on their own lunar calendar in order to establish the dates of new moons and festivals even when the Julian calendar (a solar calendar) was accepted as official everywhere. ${ }^{12}$ They counted a day beginning with nightfall, and a month, with a new moon, while, Pliny the Elder notes, the Romans counted it from midnight to midnight (Nat. 2:79). ${ }^{13}$ They were extremely careful in determining the

11 In Josephus, even the Jewish (Babylonian) months are translated into the Macedonian ones (Ant. 1.80-81; 2.311; 3.201; 3.239; 3.248; 4.84; 4.327; 8.10; 11.148; 12.248; 12.412; cf. 14.148).

12 This was definitely the case with the Jews in Alexandria. Stern ('Jewish Calendar Reckoning', 109) mentions Aristobulus (Second Century BC), who said that the day of Passover falls on the 14th of the month after evening at the full moon (cited in Eusebius, Hist. eccl. 7.32.17-18), and Philo (First Century AD), who made a distinction between the Jewish reckoning of time by a lunar calendar and the Egyptian by a solar calendar (QE 1.1). Stern also finds another evidence of a distinctively Jewish way of calendar reckoning in an inscription from Bernike, Cyrenaica (CIG 3.5361; dated the First Century BC or AD) (110). According to Galen, the Jewish lunar calendar became quite a distinctive calendar in the empire by the end of the Second Century AD because the solar calendar was adopted everywhere. Stern aptly summarises: 'One cannot help wondering whether the apparent demise of the solar calendar among the Jews, at precisely the same time as the solar calendar was being adopted by the non-Jews, was not the result of some deliberate attempt by Jews to achieve social and cultural distinctiveness within the Greco-Roman world. It remains, at least, an undeniable fact that by the end of the first century AD the lunar calendar had become among Jews a marker of their distinct identity' (114).

13 Colin Humphreys has recently suggested that the pre-exilic Jewish calendar reflected in Exod. 12:1-2 was an adaptation of the Egyptian religious lunar calendar in which a day started at sunrise and a month, on the first day of invisibility of the old lunar crescent (conjunction of the moon with the sun) and that Jesus, a Galilean Jew, most likely knew this original Jewish calendar in celebrating the Passover in his last week (cf. Ezek. 11:12; 45:21; m. Pesahim 4.5; Josephus, Bell. 5.99), while the priests of the temple used the official lunar calendar of the time, namely, the post-exilic Babylonian style lunar calendar, in which a day started at sunset and a month, on the first day of visibility of the new lunar crescent (The Mystery of the Last Supper: Reconstructing the Final Days of Jesus [Cambridge: Cambridge University Press, 2011]: 121-68). His suggestions are, however, open to criticism. Above all, his contention about the pre-exilic Jewish calendar seems less convincing because in Exod. 12:18 the seven days of the Festival of the Unleavened Bread are counted from 
first day of Nisan because it was considered the New Year Day for their religious festivals (m.Rosh HaShanah 1:1; t.Rosh HaShanah 1:1). ${ }^{14}$ In order to celebrate the Passover at full moon after the spring equinox, they sometimes intercalated a month (Second Adar) just after Adar. ${ }^{15}$

It can also be mentioned that first-century Diaspora Jews in the empire strictly followed the seven-day week cycle, at the conclusion of which the Sabbath falls. The seven-day week cycle itself may not necessarily point to a Jewish distinctiveness for it can be compared to the astrological seven-day week cycle that also coexisted with the nundinal (eight-day) week cycle in the empire in the First Century. Dio Cassius tries to closely relate the Jewish seven-day week cycle to the astrological one when he identifies the Jewish Sabbath with $\dot{\eta}[\dot{\eta} \mu \varepsilon \dot{e} \rho \alpha$ toũ Kpóvou (a Greek equivalent of dies Saturni) (Roman History 37:16:2-3; 37:17:3; 49:22:4-5; cf. Justin, 1 Apology 67:1-7 [(†

evening to evening, not from morning to morning. It also seems unlikely that Jesus counted a day differently to observe the Sabbath or any of the Jewish festivals. For example, the Sabbath disputes between Jesus and the Pharisees were not so much about when the Sabbath begins as about what one can or cannot do on the Sabbath

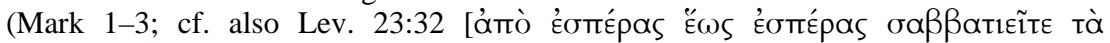
$\sigma \alpha ́ \beta \beta \alpha \tau \alpha \dot{u} \mu \tilde{\omega} v])$. Moreover, the Gospel writers simply presuppose a sunset-to-sunset day in their descriptions of Jesus' burial on the eve of the Sabbath (Mark 15:42; Luke 23:54; John 19:31; cf. Matt. 27:57, 62).

14 According to the Talmudic traditions, the beginning of a month (rosh hodesh), which coincides with the new moon, had to be confirmed and declared to be hallowed by the highest court in Jerusalem (the Sanhedrin) and notification sent through the messengers to the Jewish communities in Palestine and in the Diaspora (b. Arakhin 11b; cf. m. Rosh HaShanah 1.4, 9; 2.5; 4.4). See further S. Safrai and M. Stern, eds., The Jewish People in the First Century (CRINT; Philadelphia: Fortress, 1976): 844-45; Emil Schürer, The History of the Jewish People in the Age of Jesus Christ (175 B.C.A.D. 135), rev. and ed. Geza Vermes and Fergus Millar (vol. 1; Edinburgh: T\&T Clark, 1973): 591; Naomi Cohen, Philo's Scriptures: Citations from the Prophets and Writings (Leiden: Brill, 2007): 233 n. 9; Emanuel Rackman, Studies in Torah Judaism: Sabbaths and Festivals in the Modern Age (New York: Yeshiva University, 1961): 30: 'Talmudic and Midrashic literature makes it symbolically clear that when the Lord and His angels want to know when Rosh Hashanah occurs they themselves consult Israel's highest court, the Sanhedrin (Shemot Rabbah 15:2).'

15 Schürer, History of the Jewish People, 1:593: 'The rule according to which it was decided whether to intercalate or not was very simple: the feast of Passover, to be celebrated at full moon in the month of Nisan (14 Nisan), must always fall after the vernal equinox ... when the sun stood in the sign of Aries.' Josephus (Ant. 3.248) also states that the Passover falls when the sun is in Aries. Rackman (Studies in Torah Judaism, 31-32) points out that the Sanhedrin also considered people's convenience when they fixed the beginning of Nisan, in which Passover falls and the Omer was to be offered (b. Sanhedrin 11b). 


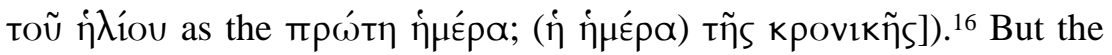
observance of the Sabbath (a day of rest) based on a seven-day week cycle was no doubt one of the prominent Jewish identity markers in the first-century Roman world. ${ }^{17}$

The seven-day week cycle also played an essential part in their celebration of three annual pilgrim festivals. The Festival of Unleavened Bread and the Festival of Tabernacles lasted for seven days (viz. a week) (Lev. 23:5-8, 34-36; Josephus, Ant. 3:249; 11:110). And Pentecost (the Feast of Weeks) had to be kept on the fiftieth day after the Passover (or seven weeks after the offer of the Omer [firstfruits] on the day following the Passover) (Lev. 23:15-16; Deut. 16:9).

The Diaspora Jews usually celebrated these pilgrim festivals where they resided. IJO 2:196 indicates that the Festival of Unleavened Bread ( $\dot{\eta}$ Éoprì $\tau \tilde{\omega} v$ ă $\zeta u ́ \mu \omega v$ ), immediately followed by the Passover and

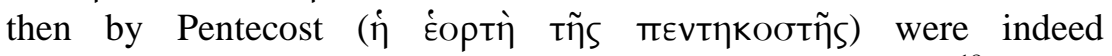
remembered and celebrated by a Jewish family in Asia Minor. ${ }^{18}$ But the Diaspora Jews, out of piety, also made a special trip to Jerusalem to celebrate one of those festivals (e.g. Philo, Spec. 1:12:68-70; Prov. 2:64; Josephus, Ant. 14:337; 17:254; Bell. 1:253; 2:42-43). ${ }^{19}$ This was the case even with Jews in Asia Minor (cf. Josephus, Ant. 16:172; Philo, Legat. 40:313-15). Luke makes it clear at two different

16 In his discussion on the seven lights on the sacred candlestick Philo explicitly names all seven planets represented by them-although he does not give any hint on the astrological seven-week cycle (Her. 1.221-24).

17 See, for example, Horace, Satire 1.9: 'I remember it very well; but will tell it you at a better opportunity: today is the thirtieth sabbath. Would you affront the circumcised Jews?' The Jewish religious privileges, including Sabbath keeping, in Asia Minor were protected by the Roman authorities (Josephus, Ant. 14.213-16, 225-27; 16.160-65, 16770; Philo, Legat. 23.155-58; 30.311-17; for more sources, see L. H. Feldman and M. Reynold, eds., Jewish Life and Thought among Greeks and Romans: Primary Readings [Minneapolis: Augsburg Fortress, 1996]: 77-102).

18 Hananyah's letter to his brother and his colleagues in the Jewish garrison can also be mentioned because he gives them an instruction on the celebration of the Passover in Elephantine, another Hellenistic city in Egypt (AP 21 [Berlin, St. Mus. P. 13464, dated 419 BC]; James M. Lindenberger, ed., Ancient Aramaic and Hebrew Letters [Atlanta: Scholars Press, 1994]: 56-58).

19 Cf. Gregory Stevenson, Power and Place: Temple and Identity in the Book of Revelation (New York: Walter de Gruyter, 2001): 140: 'Geographical separation did not necessarily entail religious isolation from the temple. Many Diaspora Jews took part in the worship through pilgrimages to the temple for religious festivals. These pilgrimages were seen as a sign of one's piety and faithfulness and they fostered religious and social solidarity. Of course, not all Diaspora Jews were able to make such a journey; yet even if a few Jews from a particular community or synagogue made the trip, it likely created a shared sense of participation.' 
occasions in the book of Acts that there were some Jews from Asia who visited Jerusalem to celebrate the Festival of Pentecost (2:9, 11; 21:27-29)..$^{20}$

\section{Jewish Time Reckoning in Paul's Letters}

In his letters Paul never mentions a specific date-whether Jewish, Roman, or Macedonian-for his letter-writing or any of his activities. ${ }^{21}$ Nonetheless, Paul does provide-if not frequently-a specific time frame for his experiences/activities, which reveals the distinctiveness of the Jewish calendar reckoning.

Above all, Paul seems to demonstrate his Jewish way of understanding a day in three different letters (2 Cor. 11:25; 1 Thess. 2:9; 3:10; 2 Thess. 3:8). In 2 Corinthians 11:25, he states that he has been shipwrecked and has stayed in the sea 'a night and a day'

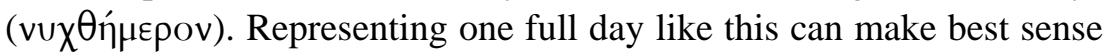
when he had in mind a sunset-to-sunset day. Similarly, in 1 Thessalonians, he claims that he worked 'night and day' (vuktòs kaì

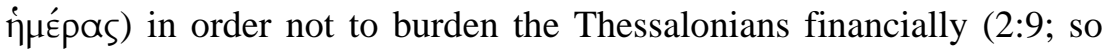
2 Thess. 3:8) and prayed 'night and day' so that he might be able to see their face again (3:10; cf. Mark 5:5; 1 Tim. 5:5; 2 Tim. 1:3). The phrase 'night and day' indeed appears both in the Scriptures (Deut. 28:66; 1 Sam. 25:16; Isa. 34:10; Jer. 14:17; cf. also Gen. 1) and Jewish literature (Jdt. 11:17; 1 En. 18:6; Josephus, Ant. 2:274; 8:108; 16:26; cf. m.

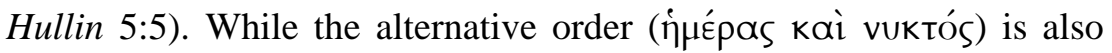
attested elsewhere in the New Testament (Luke 18:7; Rev. 4:8; 7:15; 12:10; 14:11; cf. Ps. 1:2; 42:3; Isa. 60:11), it is interesting to note that Paul consistently chooses the Jewish way of representing one full day (a night and a day) in his letters (see also Acts 20:31; 26:7).

Second, the phrase 'the first day of the week [katò fíav

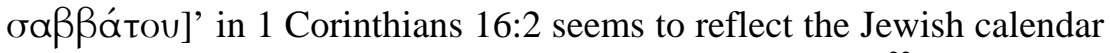
reckoning (cf. also 4Q317 1+1a ii.10 [be'khad leshabbat] ${ }^{22}$; Mark 16:2;

\footnotetext{
20 According to Acts 21:27-29, it was the Jewish pilgrims from Asia that accused Paul of defiling the temple because they thought he had brought Trophimus, an Ephesian Gentile Christian, into it.

21 This may not be surprising because the majority of extant papyrus letters do not specify the date of composition (cf. 2 Macc. 11:21, 33, 38; Ign. Rom. 10:3).

22 The reference comes from Jonathan Ben-Dov, Head of All Years: Astronomy and Calendars at Qumran in Their Ancient Contexts (STDJ 78; Leiden: Brill, 2008): 141.
} 


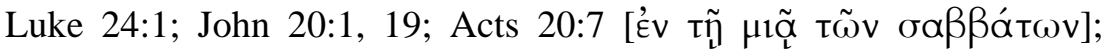

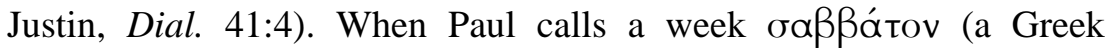
equivalent of Hebrew shabbat) he may well presuppose a Jewish seven-day week cycle. In this passage Paul asks the Corinthians to set aside some money from their income for the poor saints in the Jerusalem church regularly on every first day of a seven-day week, namely, on Sunday (cf. 2 Cor. 9:5) ${ }^{23}$ In the first-century Roman world, the voluntary associations and societies also had a periodic gathering that included a communal meal-whether on a yearly or monthly basis. ${ }^{24}$ But the Corinthians' periodic gathering on the first day of each seven-day week implied in 1 Corinthians 16:2 may have been influenced by the Jewish practice of gathering regularly on a weekly basis for the Sabbath meal at private homes (cf. 1 Cor. 11:17-34). ${ }^{25}$

While in his letters Paul does not explicitly state whether he himself observed the Sabbath at Corinth or is doing so at Ephesus in whatever ways, 1 Corinthians 9:20 may indicate that if there was no interference by his fellow Jews who were under the Law he would be willing to participate in worship at the Jewish synagogues on the Sabbath in order to save some of them. This possibility can be confirmed by Acts 18-19, where Paul is said to have gone to the synagogues regularly on Sabbaths during his stays at Corinth and Ephesus (18:4 [katà mãv

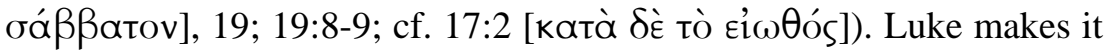
clear that whenever he was at a synagogue Paul reasoned ${ }^{26}$ from the Scriptures with the Jews and God-fearing Gentiles who happened to be

23 The first day of the week was later called 'Sunday' (Justin, 1 Apol. 67.1-7), 'the eighth (day)' (Justin, Dial. 41.4; Tertullian, On Idolatry 14.6), and 'the Lord's day' (Rev. 1:10; Gosp. Pet. 9.34-35; 12.50-51; Clement, Miscellanies 7.12.76.4; Eusebius, Hist. eccl. 3.27.5).

24 Valeriy A. Alikin, The Earliest History of the Christian Gathering: Origin, Development and Content of the Christian Gathering in the First to Third Centuries (Supplements to Vigiliae Christianae 102; Leiden: Brill, 2010): 18, 25.

25 Alikin argues against the attempts to 'trace the Christian communal gathering exclusively to a Jewish or a pagan tradition' because periodical gathering accompanied by a meal was 'a common widespread Hellenistic socio-cultural tradition' (Earliest History, 285). Yet, he still admits that the Jewish practice of the Sabbath meal in a family on a weekly basis could have contributed to the weekly cycleas an origin of the early Christians' periodical gathering accompanied by a meal (Alikin, Earliest History, 293). supper held in their meetings (Earliest History, 37). Whether the Sabbath meal was held on Friday or Saturday evening in the First Century, the influence of the Jewish calendar's reckoning on the regularity of a Christian gathering seems undeniable.

26 In Acts 17-19 Luke consistently uses $\delta 1 \alpha \lambda \varepsilon^{\prime} \gamma o \mu \alpha_{1}$ (to reason or argue) to describe Paul's activities in synagogues on the Sabbath. 
there. As for his Gentile believers who were not under the Law, however, he would not ask them to observe the Sabbath as any Jew in their neighbourhood would do (Gal. 4:10; cf. Col. 2:16; Justin, Dial. 10:3; Acts Pet. 1:1; Tertullian, On Idolatry 14:6). According to the book of Acts, Gentile believers' Sabbath observance was not part of the rulings of the apostolic council at Jerusalem (15:20, 29).

Third and last, Paul's references to the Jewish festivals may also be mentioned. It is evident from Galatians 4:10 and Romans 14:5 that Paul was familiar with the Jewish practices of attaching more importance to one day (or week) over against another. But in these passages Paul shows a different perspective on such practices. In Galatians 4:10-11 Paul warns the Gentile believers in Galatia against observing

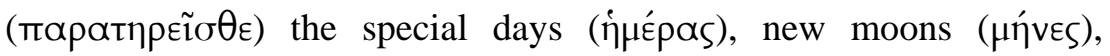
seasons (kaıpoí), and years ('́viavtoí) as the Judaisers asked them to

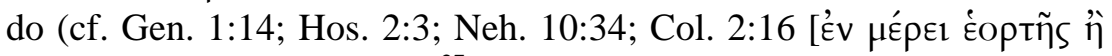

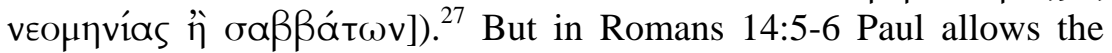
one with weak faith (most likely a Jewish Christian who would avoid eating unclean food including meat sacrificed to idols to observe the ceremonial parts of the Jewish laws literally ${ }^{28}$ ) to attach more importance to one day over against another if only he or she does it for the sake of the Lord (cf. Rom. 14:13-23; 1 Cor. 8, 10:23-11:1). Therefore, we can know that Paul's attitude toward the Jewish special days, new moons, and festivals varied according to context: whether Jewish Christians observe the Jewish festivals is a matter of adiaphora (on the condition that they do so for the Lord Jesus), whereas such observance is not adiaphora for the Gentile Christians.

Given this attitude then, Paul's reference to the Passover/the Festival of Unleavened Bread in 1 Corinthians 5 may be surprising for he asks his Gentile converts at Corinth to 'celebrate the festival with unleavened bread' (v. 8). He does not feel it necessary to explain what the Passover is, assuming their understanding of it. Instead, he goes on

\footnotetext{
27 Richard B. Hays points out that by using the generic terms 'days and months and seasons and years' (as is written in Gen. 1:14) rather than specific terms for Jewish observances in this passage (as in Col. 2:16), Paul tried to emphasise the breaking-in of the new creation order in Christ. He states: 'If this text [Gen. 1:14] no longer provides a warrant, as it did in Judaism, for observing special times and seasons, it can only be for the same reason that there is no longer "male and female" in Christ' ('The Letter to the Galatians', The New Interpreter's Bible, vol. 11 [Abingdon Press, 2000]: 288).

28 Cf. also Charles E. B. Cranfield, Romans 9-16 (ICC; Edinburgh: T\&T Clark, 2004 [reprint of 1979 edition]): 694-95.
} 
to explain how they can celebrate the festival (the Passover/Festival of Unleavened Bread) properly in the light of the fact that Christ, the Paschal lamb, has already been sacrificed. Then, in 1 Corinthians 16, Paul mentions another Jewish pilgrim festival, namely, Pentecost. In verse 8 he says, 'But I will stay on at Ephesus until Pentecost'. Unlike in chapter 5, Paul does not ask the Corinthians to celebrate this festival. He only mentions it as a time indicator for his forthcoming travel plan. But again, he does not feel it necessary to explain what Pentecost is, assuming the Corinthian believers' knowledge of it. ${ }^{29}$

In summary, it seems quite probable that Paul consistently follows the Jewish calendar reckoning in his letters to the churches in Corinth, Thessalonica, and Galatia, although he does not use any specific Jewish dates in them, and that he expects his Gentile converts in Corinth to understand the time indicators he mentions - the two Jewish pilgrim festivals in particular-in 1 Corinthians. ${ }^{30}$ This leaves the impression that Paul and his Gentile converts largely shared the Jewish calendar reckoning.

\section{Jewish Pilgrim Festivals and Paul's Ministry with the Gentile Churches}

\subsection{The Passover and Paul's Halakah Teachings and Practices}

As observed earlier, when Paul mentions two of the Jewish pilgrim festivals in 1 Corinthians, he simply presupposes the Corinthians' understanding of them. What then did Paul teach his Gentile converts at Corinth about such Jewish festivals, and what practices did he himself show them in regard to those festivals when he was with them at Corinth for one and a half years (cf. Acts 18:11)?

\footnotetext{
29 The date of Pentecost can be discerned only by the Jewish calendar reckoning. Pentecost is seven weeks (forty-nine days) after the offering of the Omer on the second day of the Passover (or fifty days after Passover).

30 According to Acts, both at Corinth and Ephesus, Paul and the Christian churches he found there were considered to be part of a Jewish sect. The proconsul of Achaea declined the Jews' accusation against the Christian church because he believed the dispute was about the language (18:15). And the silversmiths of Artemis accused the Christian church at Ephesus because Christians propagated their view that something handmade cannot be a god, which is the most fundamental doctrine of Judaism; they could not tell the difference between Christians and Jews (19:26).
} 
It is widely recognised that Paul wrote 1 Thessalonians at Corinth during his first stay. It seems likely, by implication, that Paul also taught the Corinthians what he had written in 1 Thessalonians. Unfortunately, however, the Jewish festivals were not an issue to be addressed then, and therefore, 1 Thessalonians is not much help in this regard. But it seems certain from 1 Thessalonians 4:1, 12 that Paul was interested in passing down the Christian halakah tradition to his

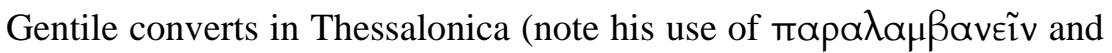
тврітатєі̃v; cf. also 1 Thess. 2:12; 2 Thess. 2:15; 3:6-7, 11). Paul's halakah tradition in 1 Thessalonians includes not only his doctrinal teachings but also sets of the rules for Christian life and behaviour that are in accordance with those teachings.

Paul shows a similar interest in such a Christian halakah tradition even in 1 Corinthians, which he composed at Ephesus. For example, in 4:16-17, Paul mentions his ways (ódoí) in Christ in which the Corinthians should walk along with him, about which he also teaches in every church, and of which Timothy will remind the Corinthians. And in 11:2, Paul praises the Corinthians for upholding the traditions that he has transmitted to them, particularly his tradition regarding the gift of prophecy and prayer in the context of communal worship. And in 11:23, he reminds them of the Eucharist tradition that Jesus himself initiated on the night he was handed over and that has been passed down to him and then to them. He exhorts them to participate in the Eucharist with discernment when they gather together as a church (11:18, 20, 33). However, he does not provide any specific instructions on when, how often, and where they are to meet in order to eat and drink from the Lord's Table (cf. 10:21; 11:22, 34). Also, in 15:1-5, he reminds them of the common kerygma of Christ's death and resurrection that he received and has passed down to them. All these references show his strong interest in transmitting the Christian halakah tradition to his Gentile converts at Corinth. And according to the Jesus tradition, both the Eucharist and the death and resurrection of Jesus are connected to the Passover/Festival of Unleavened Bread

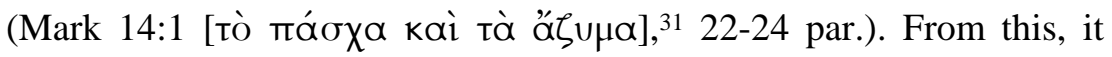
may be suggested that Paul had already taught the Corinthians the significance of Jesus' death and resurrection in connection with the

31 Josephus similarly mentions that the Festival of Unleavened Bread was often called

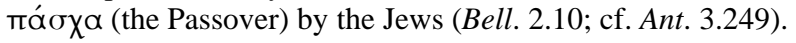


Passover/Festival of Unleavened Bread as indicated in the Jesus tradition.

Paul does not explicitly state whether he himself celebrated the Passover/Festival of Unleavened Bread when he was at Corinth. But in 1 Corinthians 5:8, Paul asks the Corinthians to 'celebrate the festival with unleavened bread'. Still, he makes it clear that he is not asking them to celebrate the festival as a typical Jew would do-namely, to search out and remove all the leaven from the house or even kill the lambs-but is trying to help them apply the principle of 'no leaven' figuratively in their dealing with the incestuous man. Besides, because Jesus has already been sacrificed as the paschal lamb, they would need no other paschal lamb to be sacrificed (5:7; cf. also 11:25; 15:3). Such typological understanding of Christ would make it unlikely that Paul himself celebrated the Passover either at Corinth or at Ephesus as a non-Christian Jew in the Diaspora would typically do. He indeed would celebrate the festival, but only in the new light of Christ's sacrificial death. And he expects the same from the Gentile believers at Corinth.

With regard to Pentecost, he never asks the Corinthians to celebrate it in whatever way. But he himself must have understood and taught them the significance of this festival for the Christian church, particularly for the Gentile churches, during the earlier period of his ministry. The church began with the outpouring of the Holy Spirit on the day of Pentecost (Acts 2:1-42). This was made possible only because Christ was exalted on high and enthroned at the right hand of God the Father (Acts 2:23-26; citing Ps. 109:1 LXX). Paul also emphasises that Christ is the Lord who reigns as God's viceroy until the final victory is won and will come to judge (1 Cor. 1:7-8; 4:5; 15:25-27 [alluding to Ps. 110:1]; 16:22; cf. Eph. 4:10-12; Col. 3:1). And the outpouring of the Holy Spirit upon the Gentile believers is the clearest evidence that they also have become children of God through their faith in Christ Jesus (Gal. 3:1-5; 4:6; 5:16-25; cf. also 1 Cor. 12:3, 13; Rom. 8:14-15; 2 Cor. 1:18-22; Titus 3:4-7). What is more, in 1 Corinthians $12-14$, he not only teaches the Corinthians how to use their spiritual gifts (such as prophesying and speaking in tongues) properly in the church, which is the body of Christ, but also presents himself as an example of proper Christian practice regarding spiritual gifts (see esp. 14:5). Therefore, it seems quite probable that Paul, having reinterpreted the Festival of Pentecost in the light of what had 
been fulfilled in Christ on this day, develops a Christian halakah tradition on the spiritual gifts. Yet it is rather uncertain whether he asked his Gentile converts either at Corinth or at Ephesus to celebrate Pentecost in any particular way.

\subsection{Pentecost and Paul's Travel Plan}

It has often been suggested that Paul probably mentions the Passover and Pentecost because he was composing the letter at Ephesus during the fifty-day interval between the two Jewish pilgrim festivals. ${ }^{32}$ In fact, in 1 Corinthians 16:8, Paul makes it clear that Pentecost is still in the future and that he doesn't intend to travel until Pentecost. On the surface, he appears to have delayed his departure because of the vast opportunities for evangelism in Asia. But he also seems to have another reason for the delay: he probably did not want to create trouble by travelling during a festival when Jews considered it unlawful, as Josephus describes in Ant. 13:252 ('Nor is it lawful for us to journey, either on the Sabbath day, or on a festival day').33

This observation may be confirmed by the Lucan accounts of Paul's journey in the book of Acts. According to Acts 20:6, on his way to Troas, Paul visited Philippi and stayed there until the Festival of Unleavened Bread was finally over. And he tried hard to arrive at Troas via ship in five days. Furthermore, it is clear from verses 6-7 that Paul (and his companions) stayed in Troas for seven days, at the conclusion of which a Sabbath fell, and that he was willing to leave the city in the morning of the first day of the week (Sunday). And in 20:16, we hear about Paul's decision not to visit Ephesus simply because he wanted to save time so as to arrive at Jerusalem before the forthcoming Jewish pilgrim festival, namely, Pentecost. Paul's travel plan during the interval between the Passover and Pentecost described in Acts 20 may also reflect a typical endeavour of a Jew to avoid travelling during a festival or on a Sabbath. ${ }^{34}$ Although Paul in 1 Corinthians 16:8, unlike

32 Philip Carrington, The Primitive Christian Calendar (Cambridge: Cambridge University Press, 1952): 42; John C. Hurd, The Origin of 1 Corinthians (New York: Seabury, 1965): 139; A. C. Thiselton, The First Epistle to the Corinthians: A Commentary on the Greek Text (NIGTC; Grand Rapids: Eerdmans, 2000): 408.

33 According to 2 Macc. 8:25-27, Maccabeus's forces stopped pursuing the enemy in order not to violate the Sabbath as it was one day before the Sabbath [ $\dot{\eta}$ про̀ тoũ

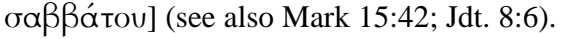

34 A Jewish reckoning of time can also be discerned from the fact that Paul broke bread in the evening of the first day (Saturday after nightfall) and talked through the night until dawn of the next day (Sunday morning). 
in Acts 20, wants to stay in Ephesus until Pentecost (is over) it seems possible that he also has a similar reason in mind. ${ }^{35}$

\subsection{Jewish Pilgrim Festivals and the Gentiles' Collection for the Saints in Jerusalem}

In 1 Corinthians 16:1-4, Paul instructs the Corinthians concerning the collection ( interesting to note here that Paul considers the collection for the saints something that each of the Gentile believers at Corinth ("Ékortos $\dot{v} \mu \tilde{\omega} v$ )—as well as at Galatia—can do on a regular basis (katò $\mu$ íav

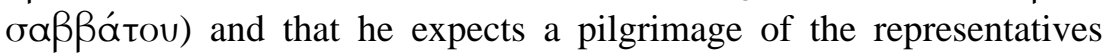
from the Gentile churches (including the church at Corinth) to Jerusalem to convey the collection to the poor Christians in the city.

This is what the Diaspora Jews all over the empire also indeed did regularly in the First Century (Philo, Spec. 1:76-78; cf. also Matt. 17:24-27). They collected the temple tax and stored it in a certain place until they could finally convey it to Jerusalem on one of the three annual pilgrim festivals (m. Sheqalim 3:1). As Mikael Tellbe points out, the temple tax was considered one of the significant identity markers for the Diaspora Jews in the First Century. ${ }^{36}$ Interestingly, in the Hellenistic Jewish literature the temple tax was often associated

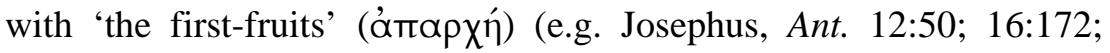
Philo, Legat. 312; Spec. 1:76-78). And it is suggested in the Mishnah that those who are living in the land of Israel may bring the temple tax at Passover, those living in the cities around it, at Pentecost, and those who are coming from more distant cities, at the Festival of Tabernacles

35 Thiselton, First Epistle to the Corinthians, 133, suggests that Paul wanted to stay until Pentecost at least partly because the mid-spring, when Pentecost falls, was 'a favorable season for travel, as in vv. 5-7'. This may also be part of the reason for Paul's plan to stay at Corinth until Pentecost.

36 Mikael Tellbe, 'The Temple Tax as Identity Marker' in The Formation of the Early Church, ed. Jostein Ådna (Tübingen: Mohr Siebeck, 2005): 23-24: 'In this way, the Temple tax also carried an essential ethnic and social meaning as it served to reinforce the individual's sense of belonging to a local social unit and tied all the families of the Jewish community together. In relation to Rome, the collection of the Temple tax served as a reminder for the Diaspora Jews of their primary affiliation. Thus, to pay the Temple tax was a tangible expression of first-hand loyalty to the Jewish nation and its religious leadership. The impression conveyed by especially Josephus and Philo is that the Temple tax was a significant marker of Jewish identity in the first century BC and the first century AD, in particular for the Diaspora Jews, for whom this tax became one of the most explicit ways to express support of cultic Judaism. In short, it was a concrete way to declare oneself a Jew and to be reckoned as one by one's neighbors'. Cf. also Stevenson, Power and Place, 141. 
(m. Sheqalim 3:4). ${ }^{37}$ Josephus reports that the Jews in Asia were passionate in collecting and conveying the temple tax and 'the firstfruits' to Jerusalem (Ant. 12:50; 16:172; cf. also Cicero, Pro Flacco 28). As a Diaspora Jew, Paul himself must have been aware of the Jewish practice of collecting and sending the temple tax and the firstfruits to the temple in Jerusalem on one of the three pilgrim festivals.

In 1 Corinthians 15-16 Paul indeed uses the word 'first-fruits'

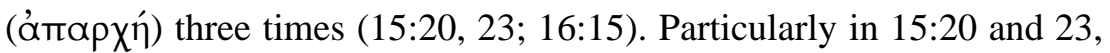
Paul states that with his resurrection, Christ has become the 'firstfruits' of those who are dead (cf. John 12:23-24, 32). Paul's language has probably been influenced by his recent experience of and reflection on the Passover/Festival of Unleavened Bread (5:6-8). ${ }^{38}$ Christ has not only been sacrificed as the paschal lamb but has also become the firstfruits of resurrection offered to God. In 16:15 Paul calls the household of Stephanas the 'first-fruits' of Achaea. Here the 'first-fruits' refers not so much merely to the first converts in the province as to those who even committed themselves to the service for 'the saints' (Eis Siakovíav toĩs áríors) (cf. also 2 Cor. 8:4; 9:1, 12; Rom. 15:16, 2526, 31; Acts 11:29; 12:25). ${ }^{39}$

It should be noted here that in 1 Corinthians Paul never calls the

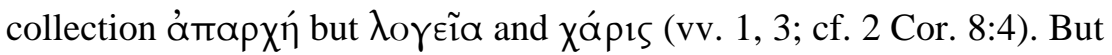
he clearly states that it is planned to serve 'the saints' (Eis toùs áríous) (cf. 2 Cor. 8:4; 9:1). And in 2 Corinthians he calls it by

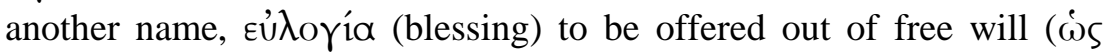

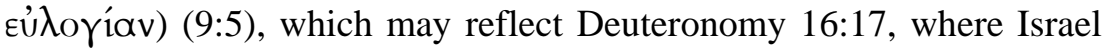
is asked to 'give as they are able, according to the blessing of the

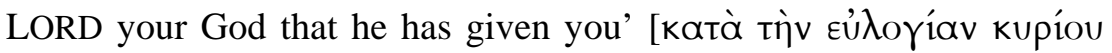
тои̃ $\theta \varepsilon$ ย festivals (NRSV; cf. also Deut. 16:10, 16). This possibility can be strengthened by Paul's use of the imagery of sowing and harvesting

\footnotetext{
37 See also Tellbe, 'Temple Tax as Identity Marker', 21.

38 John C. Kirby, Ephesians: Baptism and Pentecost (London: SPCK, 1968): 77, suggests: 'The passing reference to the first-fruits in 1 Cor. 15:20 is inexplicable without the meaning of the custom being known.' And Humphreys points out that Christ's being the 'first-fruits' of the dead may be understood against the background of the first-fruits festival of barley which took place on the second day of the Feast of the Unleavened Bread, that is, on Sunday, Nisan 16 (The Mystery of the Last Supper, 68-69; cf. Lev. 23:10-11; Josephus, Ant. 3.250-51).

39 In Rom. 16:5 Epaenetus is similarly called the 'first-fruits' of Achaea 'for Christ' [eis Xpiotóv].
} 
and his citation of Psalm 111:9 LXX in the immediate context of chapter 9 (vv. 6-10). Paul encourages the Corinthians to give generously for the poor in Judaea by stating that 'the one who sows

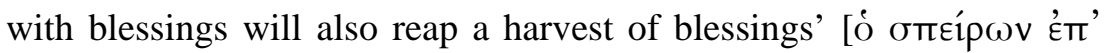

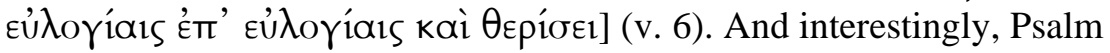
111 (MT: 112), which Paul cites in order to emphasise the grace and blessings enjoyed by the one who gives ('scatters') generously, is indeed a Hallel psalm which was sung at the Festival of the Passover, one of the pilgrim festivals. ${ }^{40}$ Based on this psalm, Paul asserts that God would enlarge the Corinthians' harvest of righteousness (tà

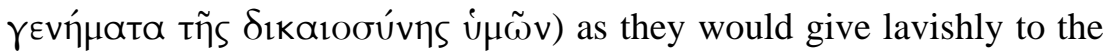
poor saints (9:10; cf. Lev. 23:39). Finally, in Romans 15:28, by calling the Gentile believers' collection for the poor saints in Jerusalem 'fruit' (карто́v), Paul makes it clear that his exhortations on the collection are based on his reflections on the Diaspora Jews' practices in celebrating the pilgrim festivals.

It seems quite likely from 1 Corinthians that Paul believes the Gentile churches' collection for the saints should be conveyed by their representatives to Jerusalem (16:3; cf. Acts 11:29-30; 20:4; 21:29; 27:2; Gal. 2:1, 10). This combination of their collection (however it is called) and their representatives' pilgrimage to Jerusalem can be best understood in light of the Jewish practices of collecting and then transmitting the temple tax along with the first-fruits to the temple in Jerusalem during one of the annual pilgrim festivals.

Paul does not explicitly mention in his letters when the collection can and should be conveyed to Jerusalem. But it is not going to happen until he can finally come over to Corinth after the forthcoming Pentecost (1 Cor. 16:3, 8). In addition, because he plans to visit Macedonia first on his way to Corinth and stay at Corinth for a while until the winter is over, it would be impossible for him to send or to travel along with the representatives from the Gentile churches to convey their collection to Jerusalem in time for the Festival of Tabernacles of that year (September/October). If so, then, the Passover/Festival of Unleavened Bread in the next year would be the earliest time for their pilgrimage.

40 Susan Gillingham, Psalms through the Centuries (Malden, MA: Blackwell Publishing, 2008): 44, 111. Cf. Frank-Lothar Hossfeld and Erich Zenger, Psalms 3: A Commentary on Psalms 101-150 (Hermeneia; Minneapolis: Fortress Press, 2011): 169. 
But as he indicates later in 2 Corinthians, Paul had to change his original travel plan and visited Corinth a second time for an unknown reason (1:15-16, 23-24). And he also had to return to Ephesus with his relationship with the Corinthians undermined (1:8-9; 2:1-2). In such a situation, he had to spend a lot of time and energy to restore his relationship with them, handle their problems, and help them complete the collection that had been delayed over a year (8:10; 9:2).

When the collection project in the Gentile churches (particularly at Corinth) is finally completed, in his letter to the Romans, Paul states his plan for a pilgrimage to Jerusalem with the collection, and asks them to pray that he should be rescued from the unbelieving Jews in Judaea (and Jerusalem) and that his 'service for Jerusalem' (which he also calls 'the fruit') should be acceptable ( $\pi \rho$ ó $\delta \delta \varepsilon$ to $)$ to 'the saints' in Judaea (Rom. 15:28, 31; cf. 2 Cor. 1:16). His deep concern about the unbelieving Jews in Judaea may suggest that he plans to visit Jerusalem during one of the pilgrim festivals for which the Jews from all over the world gather in Judaea, particularly in Jerusalem. It was indeed during the Festival of Pentecost, according to Acts 20:16, that Paul and his companions visited Jerusalem to transmit the collection to the poor saints in Jerusalem. ${ }^{41}$

In short, it seems very likely that Paul has in mind the Jewish practice of collecting and transmitting the temple tax and the first-fruits to Jerusalem at the Jewish pilgrim festivals when he exhorts the Corinthians concerning the collection for the saints in Jerusalem in 1 Corinthians 16. But he also appears to have reinvented it so that his Gentile believers might serve the saints in Jerusalem, but not the temple itself as the Diaspora Jews typically did, while the temple still existed. For him, every church is the church of 'the saints' (1 Cor. 14:33) and God's temple is where the Holy Spirit dwells (1 Cor. 3:16; 6:19).

41 Luke does not explicitly mention the Gentile church's collection for the saints in his account of Paul and his companions' visit to Jerusalem (Acts 21). But it may be implied in Acts 21:25, where James reminds Paul of the official decision by the church council many years ago, but only of the Gentile believers' need for abstaining from eating idol foods, blood, and what was strangled, and from sexual immorality. His silence on their need to help the poor saints in Jerusalem seems to indicate that Paul and his companions brought the collection in his visit to Jerusalem (cf. Gal. 2:10). 


\section{Conclusion}

In conclusion, it seems certain from his letters that Paul shared the Jewish calendar reckoning with his Gentile converts. This probability can be most clearly indicated by the fact that Paul asked the Corinthians to celebrate the Festival of Passover with unleavened bread (1 Cor. 5:8) and that he used the Festival of Pentecost as a time reference for his travel plan (1 Cor. 16:8): in both cases, he simply presupposes their understanding of those Jewish pilgrim festivals.

It also seems certain that both the Passover and Pentecost played a key role not only in providing Paul with the biblical foundations for his exhortations in 1 Corinthians but also in shaping his ministry with the Gentile churches at Corinth, Ephesus, Galatia, and Macedonia.

Paul's identification of Christ with the paschal lamb and his application of the principle of 'no leaven' to the case of the incest at Corinth appear to be occasioned by the Festival of Passover. There is no doubt that the Corinthians had been aware already of the significance of the Passover when Paul wrote 1 Corinthians. It would be difficult to tell how they celebrated this festival. But their celebration must at least have been different from that of a typical Diaspora Jew because Jesus the paschal lamb has already been sacrificed once for all. Therefore, the Corinthians whom Paul identifies with the new Passover community in 1 Corinthians 10 are supposed to celebrate the festival in the new light of Christ the paschal lamb's sacrificial death.

Paul's plan for the collection among the Gentile believers, which entails their regular (weekly) collection and their representatives' pilgrimage to Jerusalem (1 Cor. 16:1-4), may be an adaptation of the Diaspora Jews' practice of collecting and transmitting the temple tax along with the first-fruits to Jerusalem during the Jewish pilgrim festivals. Here Paul again reinterprets the Jewish practice of celebrating the pilgrim festivals in the light of what Christ has already done (his resurrection and enthronement) and reinvents it for the Gentile churches' collection ministry to serve the poor saints in Jerusalem, who can be identified with God's temple just as the Gentile believers themselves are (1 Cor. 3:16; 6:19). 